\title{
A management system to optimize reservoir control in the case of floods
}

\author{
R. Pohl \& A. Bornschein \\ Dresden University of Technology, Germany
}

ABSTRACT: Many multipurpose reservoirs are situated in the low mountain range of Germany. Most of them are necessary for drinking water supply and flood protection as well. Other utilizations are recreation, water power and the downstream low water regulation during dry seasons. The operation rules of the reservoirs have to be optimized to meet the different requirements of use. One tool within this framework is a management system for river basins including all reservoirs and their specific operation rules affecting the downstream reaches. As an optimization objective for instance the minimization of inundation risks can be defined. In this case the risk can be defined as hydraulic and hydrologic safety of the reservoir itself and the risk due to inundation and damaging in the downstream regions. Considering the European Water Framework Directive the ecological aspect of reservoir management is one more point in the optimization process. To establish a pilot project the software TALSIM will be applied to river catchments in the ore mountains (Saxony).

\section{INTRODUCTION}

In the last few years some big flood events occurred in the catchments of the rivers Elbe, Danube and Odra in Germany (figure 1). Heavy damages occurred. Thus 21 people were killed and substantial parts of the infrastructure were destroyed during the 2002 flood.
The total loss in Germany was estimated to be 11.9 billion $€$. These floods have dramatically called attention to limits and deficits of flood risk management in the affected areas. It became obviously that there was a need to develop and implement improved instruments of flood risk management by the integration of different professional disciplines and experts in different fields.

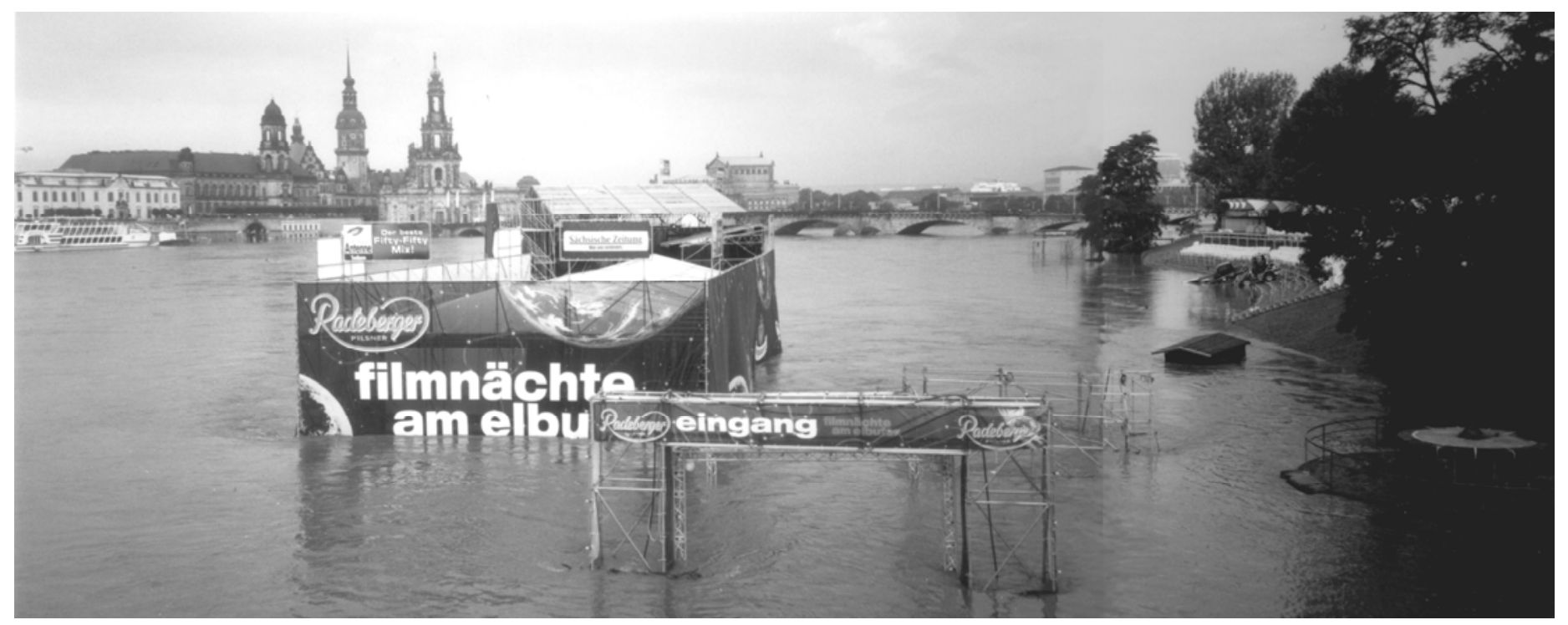

Figure 1. River Elbe with flooded open air cinema in Dresden during the 2002 flood event (photograph: Bornschein). 
The German Federal Ministry of Education and Research (BMBF) funded the national research program RIMAX (risk management of extreme flood events). The program has duration of 3 years (www.rimax-hochwasser.de). It focuses on flood events with a return period greater than 100 years and with high damage potential.

The program consists of three major subjects:

- Integrated concepts of flood risk management

- Technical flood protection

- General issues (e. q. Education, Networking, Flood awareness and Risk communication)

The general issues should warrant the knowledge transfer into practice and education as well as the national and Europe-wide network of research activities. The research program stresses on implementation, which means, that the funded projects have to collaborate with responsible organizations at different political levels.

The research program includes more than 30 research projects with partners from universities, engineering consultants, governmental organizations and dam authorities. The first projects started in summer 2005. There is a wide range of research themes such as ground water management in urban areas in the case of extreme floods, reservoir and polder management, geo-textiles, stability of dikes and levees, flood retention in river networks, flood prediction and management, flood impacts on water supply, risk management and risk prediction using historical flood data information.

\section{OBJECTIVES OF THE PROJECT}

The presented project is a joint project between the Institute of Hydraulic Engineering and Applied Hydromechanics of the University of Technology Dresden and the Institute of Hydraulic Engineering and Water Management of the University of Technology Darmstadt, both are situated in Germany.

The research work of the project is focused on the improving of tools to analyze, evaluate and to manage flood risks. The future aim is to integrate the flood risk management including the reservoir operation strategies into the river catchments management.

In the end the flood risk of a certain flood event should be reduced in terms of both the failure probability of the dams and the consequences (damages, costs, impacts etc.) in the downstream areas. This means that an optimization has to be carried out to find the reservoir operation rules with the lowest environmental impact and the highest structure safety (dams, weirs, levees). Two strategies are possible: On the one hand a risk management system can be established due to pre-calculations of possible flood events including the consideration of retention in reservoirs and polders. On the other hand a just in time calculation can help to achieve better operation rules during a flood event.

In a catchments area the reservoirs and dams, the structures in the downstream regions like weirs, dikes and levees, the urban areas, industries and agricultural might be at risk. Furthermore the preservation and the improvement of the ecological system in the river basin, in the reservoirs and the river network are very important requirements of the risk management system.

\section{INPUT DATA}

The system which comes out of the research project has to include the calculation of the discharge in the whole catchments area (precipitation-runoffcalculation), retention calculation of the reservoirs and the computation of wave propagation downstream the dams with the determination of inundation areas. Furthermore the damages occur due to the flooding have to be calculated.

This needs a wide range of input data which are described in the following paragraphs.

\subsection{Digitalized morphological data}

A digitalized morphological data set is the basis for the whole system. It determines the river morphology, the geographical data set for precipitation run off calculation and provides the information of land use and soil properties as well as the location of buildings and bridges (figure 2).

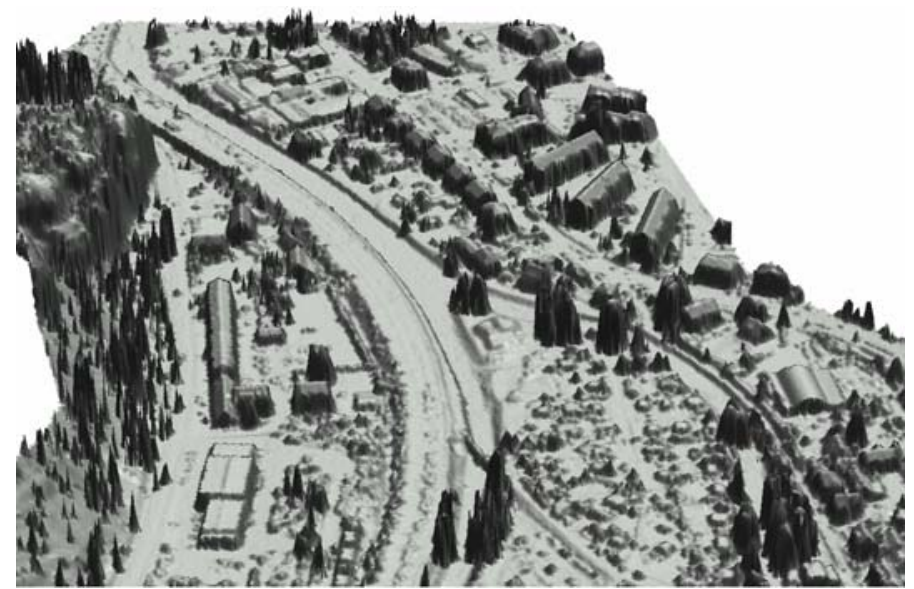

Figure 2. Morphological data set with vegetation and buildings from laser scan (confluence of the rivers Wilde Weißeritz and Rote Weißeritz at the town of Freital; data: LTV 2005).

The profiles of river cross section are often determined by terrestrial surveying. Additionally laser scan data or digital topographical maps are used for the whole watershed and the floodplains. 


\subsection{Precipitation and discharge}

To model the areal precipitation for the whole watershed, the polygon method will be used.

This method is used because of the non uniform measurement station spacing. To determine the areas belonging to each station, lines are drawn between adjacent stations on the map. The perpendicular bisectors of these lines form a pattern of polygons with one station inside each polygon (see figure 3 ). These are the areas in which the measured precipitation of each station will be used to calculate a certain event for the whole watershed.

Furthermore data are needed to estimate the maximum possible precipitation (DVWK 1997 and DWD 1997), the discharge of a flood event with a certain reoccurrence (LfUG 1993) and the soilmoisture at a certain event.

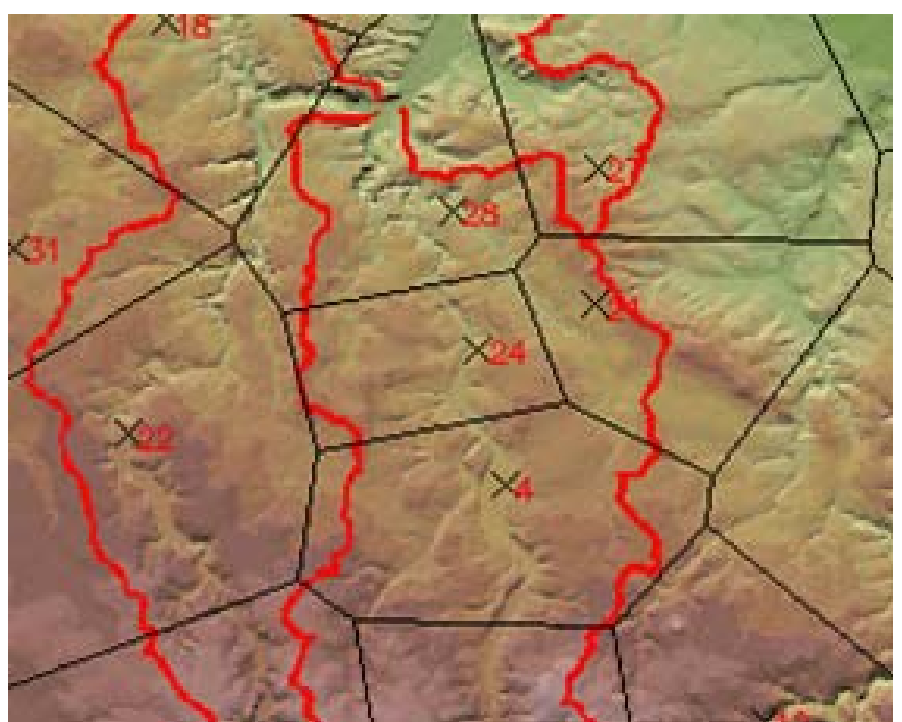

Figure 3. Polygon method to calculate the areal precipitation distribution in the catchments area of the Weißeritz river $(x=$ the location of a precipitation station; $-=$ border of the related areas).

To validate the calculated discharge from precipitation-runoff-analysis gauge data will be needed. Considering bigger flood events where the discharge measurement didn't work it is also possible to validate the discharge by use of hydraulic water level calculation and comparison with measured water levels along the river banks or at bridges and buildings.

\subsection{Operation strategies and rules for dams, reservoirs and polders}

The operation rules of a controlled reservoir determine the future reservoir water level and the outflow hydrograph depending on the inflow hydrograph, the initial reservoir water level, the actual season and the precipitation forecast. These operation rules depend on reservoir purposes like flood protection, wa- ter supply, low water regulation, fishing and recreation benefits.

There are different common operation strategies for reservoir storages and release decisions like the following:

- Determination of a minimal and maximal outflow discharge; the minimal outflow discharge often depends on ecological reasons; the maximal outflow discharge could be determined by the inbank capacity in a downstream river reach.

- For flood control purposes free reservoir storage has to provide enough volume to keep a flood of a certain reoccurrence within the reservoir. This could mean to discharge more water downstream in anticipation of a flood event.

- Water supply for drinking water or industrial water demands a defined release discharge to meet the needs.

- Controlled outflow to balance the downstream flow (reservoir storage management plan).

- Low water regulation (to ensure a critical water level for commercial navigation, thinning of wastewater inflow, fulfilment of a water supply demand downstream).

- The reservoir outflow depends on the reservoir inflow.

- Release decisions depending on other states of the system (actual water level in other reservoirs in the same or in other catchments areas, actual discharge in a special river reach, the snow height in the catchments area, actual precipitation, actual soil moisture and others).

All release decisions may vary with respect to the time. The outflow discharge is limited by the gate opening and or the spillway capacity (figure 4).

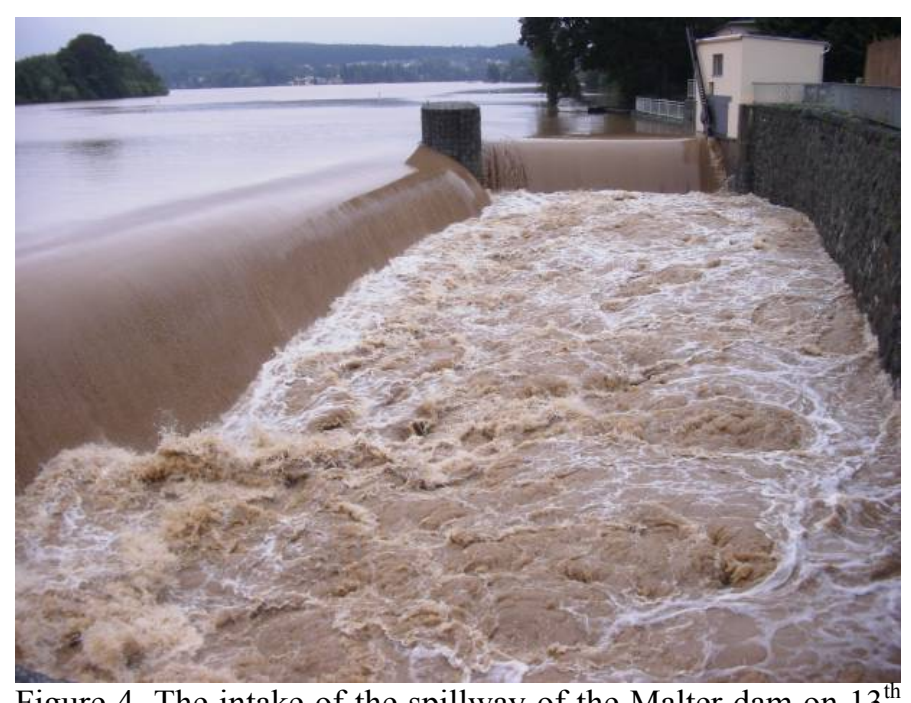

Figure 4. The intake of the spillway of the Malter dam on $13^{\text {th }}$ August 2002.

In the case of a multipurpose reservoir there are often competing purposes. One example could be flood protection and water supply. Flood protection 
needs an initially large empty flood control storage resulting in a low water level. Water supply needs a high water level because of required supply safety and the need of water extraction in different water levels to guarantee the water quality.

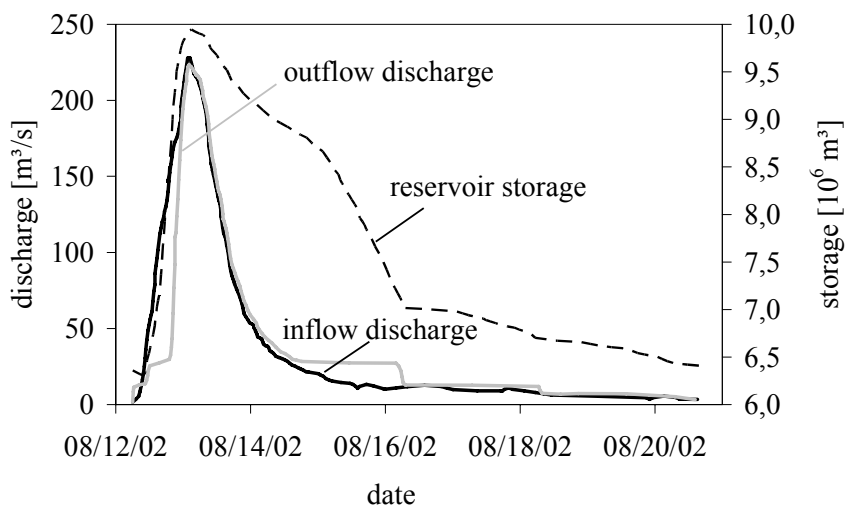

Figure 5. Inflow and outflow hydrographs as well as reservoir capacity of the Malter reservoir during the flood in August 2002 (LfUG 2002).

But in the case of an extreme flood event it is difficult to control the outflow. In figure 5 the inflow, outflow and storage hydrographs of the Malter reservoir in Saxony are shown during the flood event in August 2002. The volume of the whole flood wave was 11 times bigger than the flood detention storage of the reservoir and almost triple of the total storage volume of the reservoir. The inflow and outflow peak are almost the same.

Polders often have more simple operation rules. In the case of an uncontrolled polder the inflow begins when the water level in the river exceeds a certain level. If there is a gated inflow structure the filling of the polder can be delayed until the flood peak arrives.

\section{OPTIMIZATION CRITERIA}

The optimization process is mainly based on a multicriterion matrix which includes different types of optimization criteria.

\subsection{Freeboard and overtopping of dam}

The new German standard (DIN 19700) gives two design cases for dams. Furthermore the hydraulic safety of the dams has to be considered (Pohl \& Horlacher 1996 and Pohl 1999). In the risk management the failure frequency of gates and valves at dams has to take into consideration (Pohl 2000 and Martin \& Pohl 2002).

If the water level in a reservoir or in the river reaches a certain level the dam or levee could be overtopped. Because of the possibly unstoppable erosion process due to overtopping and the follow- ing completely destruction this must be avoided at all costs (Aigner et. al. 2002 and Bornschein \& Pohl 2003). So the level of the dam crest or the top of a levee or dike is a very strong criterion for maximum water level.

\subsection{Stability of dams and levees}

There are different stability criteria for each type of hydraulic structure like dams, dikes, levees, weirs. They are e.g. described in dam or levee standards and guidelines. Typical failure modes are sliding, overturning, erosion due to piping or overtopping.

The difference in water level outside and inside a levee has an influence on seepage and can reduce levee stability.

Just before overtopping extraordinary water surface elevation can reduce the stability of a dam. In general safety coefficients below 1 indicate insufficient stability and therefore a severe failure risk.

\subsection{Inundation damages}

The inundation of industrial and urban areas or forests and farmland results in different types of damages which are:

- Asset damages (economic, public and private)

- Production downtimes (during and after the flood event)

- Casualties

- Damage to cultural buildings or sites with considerable ideal losses

- Ecological impacts

Some of these damages were recorded or can be expressed monetarily. An advanced description of possible damage due to high water levels is a stagedamage-function. This is a summary statement of direct economic cost of flood water inundation for a specific river reach (US Army 1996). This function depends on the land use and the kind of structures within the considered area (residential structures, non-residential structures).

There is a wide range of different stage-damagefunctions. Therefore the above mentioned RIMAX program includes also research groups dealing with damage functions.

But some damages can be described only qualitatively. Therefore an evaluation system with qualitative description has to be used. A very simple example is the classification of damages into groups as high, mean, low and none.

\subsection{Ecological Impacts}

The operation of dams, the installation of weirs as well as the set up of dikes and levees change the landscape and have ecological impacts.

A qualitative calculation of this impact is very difficult or often impossible. One has to distinguish 
between the ecological impacts in mean level and low level times and in the case of a flood event.

In times of a low water level the water temperature and oxygen content have often negative impacts on protozoa, fishes and plants. The reservoir operation rules could help to avoid critical states in the stream.

But also a flood itself has negative ecological impacts although a flood is a natural phenomenon. Too frequent and too long inundation of floodplains or polders can hurt the flora and fauna. Since the velocity is high fishes may floating away during a flood event.

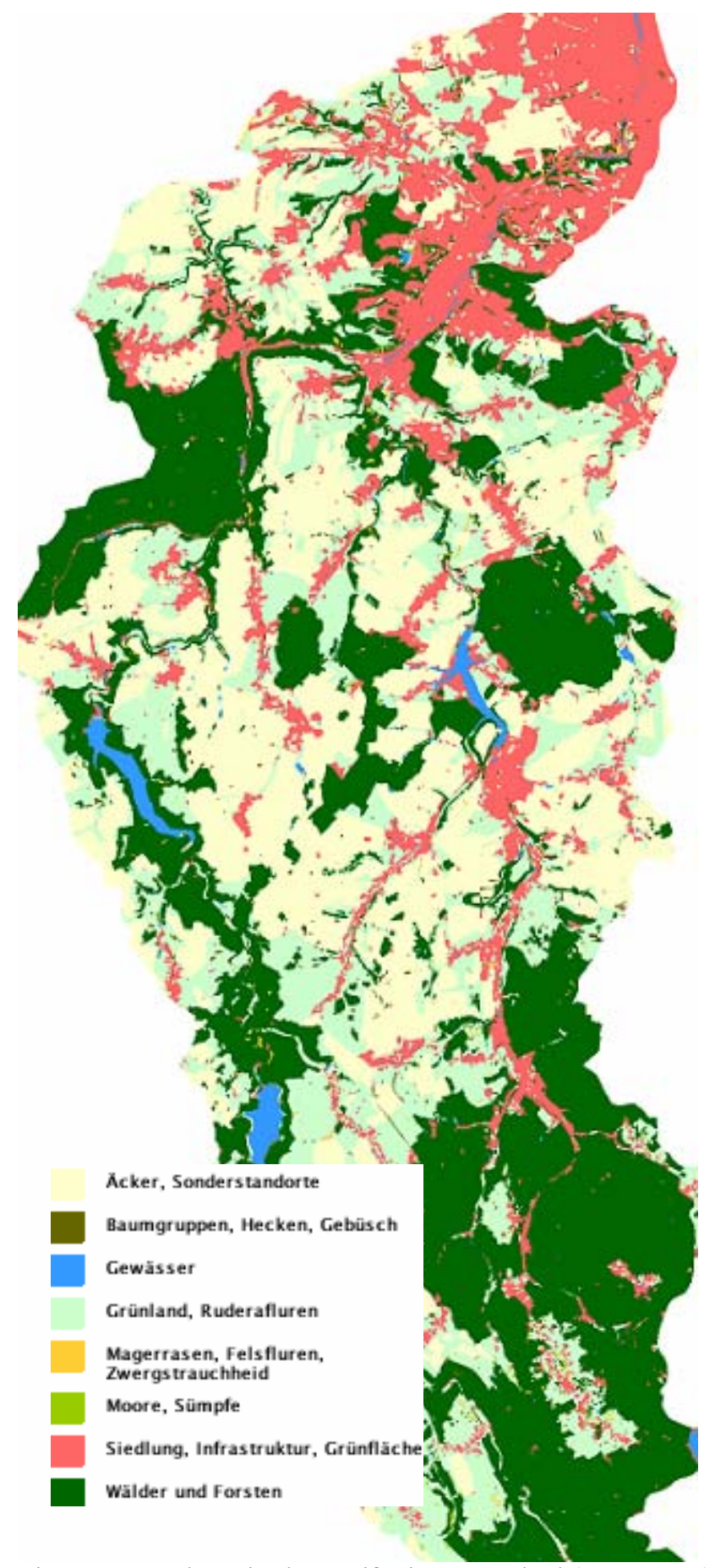

Figure 4. Land use in the Weißeritz watershed (LTV 2005).

\section{CALCULATION PROCEDURE}

To find out the optimum operation strategy several calculation steps have to be included in a calculation procedure. The separate computation steps that have to be repeated many times can be described as follow:

1 Precipitation-runoff-calculation in the whole watershed using TALSIM. The result is the discharge hydrograph in each river reach $(\mathrm{Q}(\mathrm{t}))$.

2 Determination of stage-discharge-relation at each cross section using a water level calculation for different flood scenarios.

3 Determination of a relation between a certain water level and the possible damage at a certain river reach

- allocation of a flooded area to a certain water level at each cross section

- selection of the appropriate stage-damagefunction depending on the major land use in the flooded area

- addition of all damages related to a water level at each cross section

4 determination of the relation between the amount of damage and the river discharge using the results from step 2 and 3

5 determination of a multi-criteria objective function for optimization purposes including monetary and non-monetary criteria

6 search of this operation strategy with the lowest damage for all possible flood events or the most of them

To check the different operation strategies it is necessary to use artificial flood events with a reoccurrence period of about 20 to 100 years and beyond and the series of historical flood events if recorded.

\subsection{Precipitation-runoff analysis using TALSIM}

The TALSIM software has been developed to solve water management problems including reservoirs at Darmstadt University, chair of hydrology and SYDRO-Consultants. Water management systems like a multi reservoir system or a river basin can be modelled.

The description of the water management system needs different artificial system elements. A system element yields a certain output under certain defined input conditions. Different system elements have been connected to create the whole water management system.

The following elements are available: single discharger, reservoir, customer, transport element (= river reach), branch and single catchments area. An element is described by characteristics and parameters. Characteristics can be determinate clearly like a cross section shape of a river reach. Parameters need a calibration and validation process like the roughness parameter of the river bed. A special element 
uses different methods to transform the input data into the output data.

The level of discretization of the water management system depends on possible cost and effort as well as how detailed the output is needed.

To calculate the precipitation-runoff process three models are implemented. The most simple is to define a fixed discharge coefficient for each single catchment area depending on land use, altitude and subsoil properties.

More advanced is the widely used soilconservation service method (SCS-method) or curve number method considering soil texture, land use and soil moisture. The Curve number and the total precipitation of the last 21 days are necessary for input.

The highest effort needs a complex soil moisture and ground water calculation. This model needs a wide range of detailed measured data and is only recommended for smaller catchments areas.

TALSIM is not a hydrodynamic model. The flood routing and water retention in a river network are approximated using the conceptual model of $\mathrm{Ka}$ linin-Miljukov.

\subsection{Water level calculation and determination of inundation area}

To connect the damages due to the inundation with the precipitation-runoff-model a one-dimensional hydrodynamic model has been introduced into the calculation.

A possible hydrodynamic model is HEC-RAS developed by the Hydrologic Engineering $\underline{\text { Center of }}$ the US Army Corps of Engineers (USA). It solves the one-dimensional shallow water equation and can be used for both steady state and dynamic water level calculation. Backwater effects of bridges and weirs as well as more complex cross sections can be considered.

The water level from the hydrodynamic model together with the digital morphological data set let to the inundated area due to a certain river discharge.

\subsection{Polder}

There is no special element or tool to describe a controlled polder within TALSIM. Therefore a combination of different elements has to be established.

The polder itself is represented by the element „Reservoir“. A water-level-storage-relation must be known as input. The distribution of the flow at the inflow cross section of the polder can be modelled using the element "branching" with a threshold model (figure 7). If the discharge reaches a critical value the inflow into the polder begins.

To determine the actual characteristics of inflow structure it is possible to set "selectivity" for it. Another possibility is to set a variable threshold $\mathrm{Q}_{\text {crit. }}$
The outflow from the polder can be included in an element ,river reach“. The definition of a weir or an operation rule is necessary at this cross section.
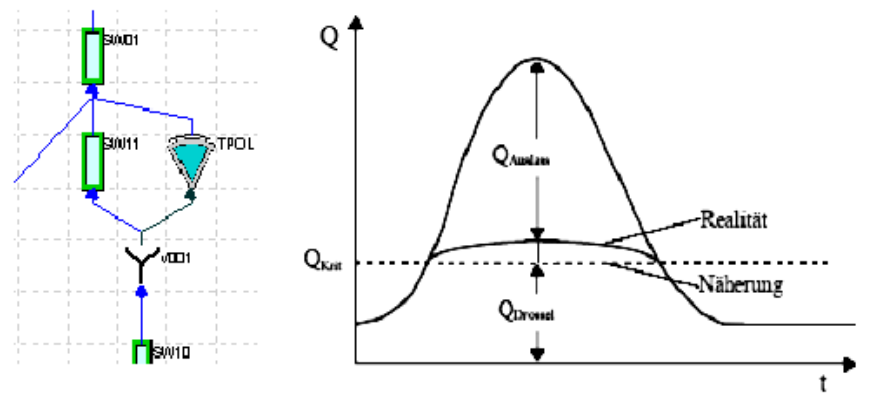

Figure 5. System elements of TALSIM describing a polder with rectangle $=$ river reach and triangle $=$ reservoir (left) and the principle of the threshold model for the polder inflow (right).

\subsection{Model calibration}

Previous flood events among them the 2002 event in Saxony are used to calibrate the model. First the modelling of the precipitation-runoff-relation has to be verified. Figure 8 shows the precipitation measured at the rain gauge Fichtelberg versus the measured and calculated discharge at the gauge Lehnmühle in the period from November 1997 to November 2004.

At the moment the agreement is not sufficient due to the assumption that the measured precipitation at one rain gauge is equal to the areal precipitation of the whole catchments area of the discharge gauge, which is about $60 \mathrm{~km}^{2}$. Therefore further data and calibration are needed.

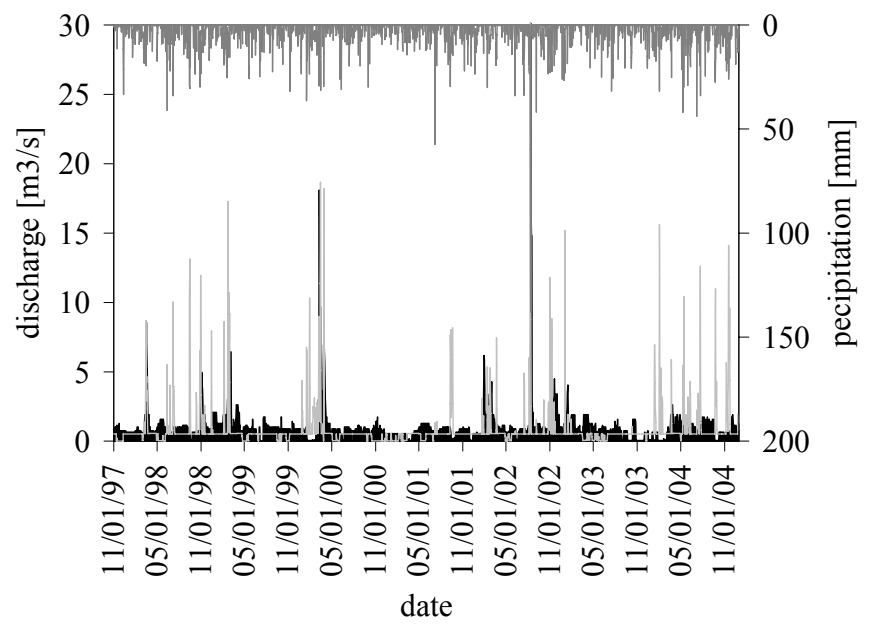

Figure 6. Measured (-) and simulated (-) water level at the gauge Lehnmühle UP together with precipitation data $(-)$ of the station Fichtelberg.

Another calibration is necessary for the hydrodynamic model and calculation of the water level. Water level and discharge measurements are required. 
The water level of the extreme 2002 flood event is available. More data of this quality would be desirable. This event represents a reoccurrence interval of about 500 years for the Weißeritz watershed (LfUG 2004).

\section{CASE STUDY}

To evaluate the effectiveness and usability of the calculation model two case studies will be carried out. The Weißeritz case study will be presented shortly.

Table 1: Catchments area, river length and altitude of the Weißeritz river (LfUG 2004)

\begin{tabular}{lrcccc}
\hline Catchments area & Area & \multicolumn{2}{c}{ River } & & \multicolumn{2}{c}{ Altitude } \\
& & \multicolumn{2}{c}{ length } & & \multicolumn{2}{c}{ max. } & min. \\
\cline { 2 - 3 } \cline { 6 - 6 } & {$\left[\mathrm{km}^{2}\right]$} & {$[\mathrm{km}]$} & & {$[\mathrm{m}$ a.s.1.] } & [m a.s.1.] \\
\hline Wilde Weißeritz & 163 & 52.9 & & 735 & 185 \\
Rote Weißeritz & 154 & 35.4 & & 765 & 185 \\
Weißeritz & 67 & 14.2 & & 185 & 110 \\
Total & 384 & 102.5 & & & \\
\hline
\end{tabular}

Three rivers belong to the Weißeritz watershed. The Rote (red) Weißeritz river and the Wilde (wild) Weißeritz river have their sources in the Ore mountains (figure 9). The Weißeritz river (also named Vereinigte (united) Weißeritz river) originate due to the confluence of these two rivers at the town of Freital (figure 2). The Weißeritz river runs into the Elbe river at Dresden.

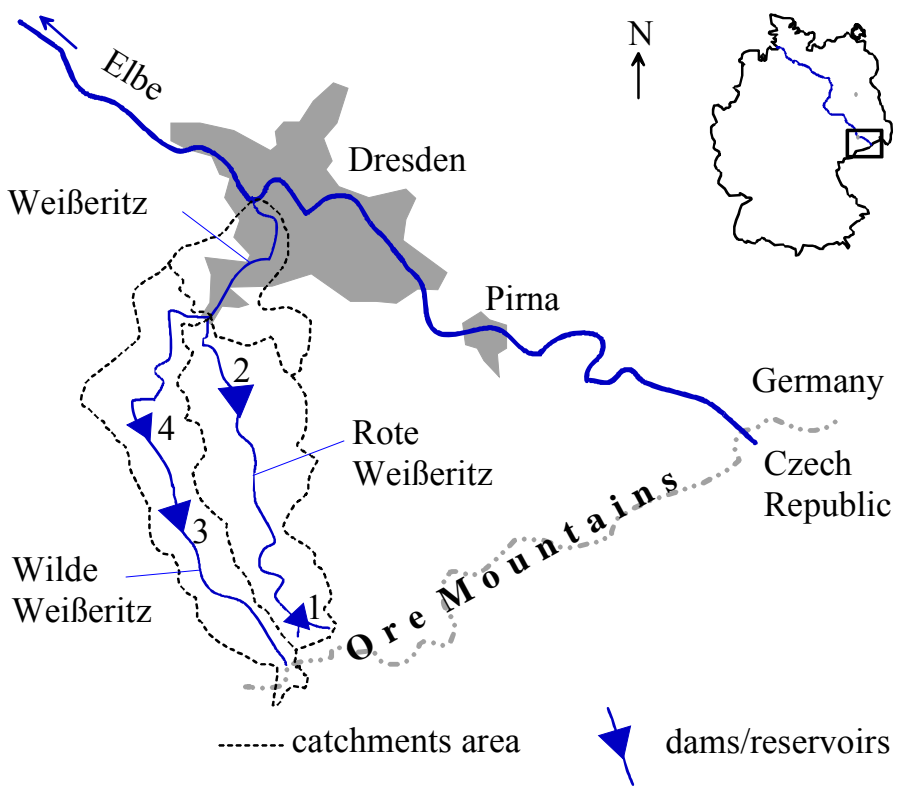

Figure 7. Catchment areas of the three Weißeritz rivers with existing dams (the numbers of the dams refers to table 2).

There are four reservoirs situated in the Weißeritz watershed all directly connected with the natural river system (figure 9 and table 2). The Rote Weißeritz river begins at the Altenberg reservoir. Furthermore the Malter dam is situated at the Rote Weißeritz river. This is a multipurpose reservoir for flood retention, water supply and recreation.

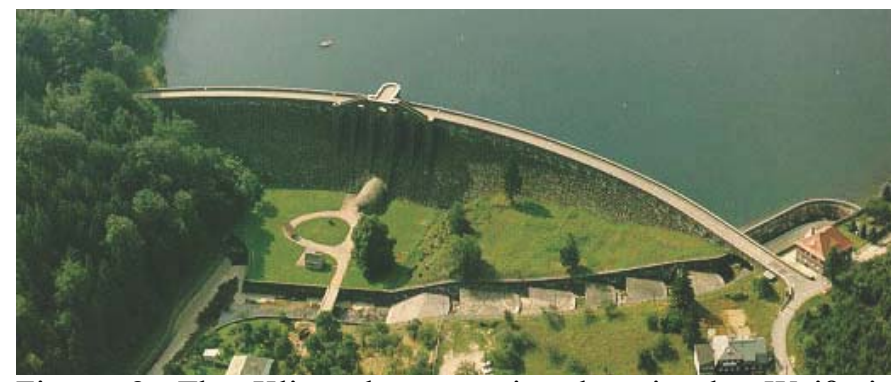

Figure 8 . The Klingenberg gravity dam in the Weißeritz catchment area (photograph: LTV).

There are the Klingenberg dam (figure 10) and the Lehnmühle dam in the catchment area of the Wilden Weißeritz river. The main purpose of these two reservoirs is the drinking water supply for the town of Freital and the city of Dresden. Another purpose is flood control.

There are 21 precipitation stations within and near the Weißeritz watershed.

Table 2. Dams in the Weißeritz catchments.

\begin{tabular}{|c|c|c|c|}
\hline $\begin{array}{l}\text { Catchments } \\
\text { area }\end{array}$ & $\begin{array}{l}\text { No. } \\
\text { of the } \\
\text { dam }\end{array}$ & $\begin{array}{l}\text { Name of the dam } \\
\text { or Storage system }\end{array}$ & $\begin{array}{l}\text { Storage } \\
{\left[10^{6} \mathrm{~m}^{3}\right]}\end{array}$ \\
\hline Rote & 1 & Altenberg & 1.036 \\
\hline Weißeritz & 2 & Malter & 9.2 \\
\hline Wilde & 3 & Lehnmühle & 23.53 \\
\hline Weißeritz & 4 & Klingenberg & 17.49 \\
\hline
\end{tabular}

\section{FIRST RESULTS}

First calculations were made to check the reliability and the results of a reservoir or polder retention model. In the case of reservoirs and polders it was very important to find the right point in time to open the outlets (dams) or inlets (polder). As already expected the results were sensitive to the reliability of the forecast of the discharge hydrograph.

As an example a polder with a reservoir surface of $\mathrm{A}_{\mathrm{p}}=2 \mathrm{~km}^{2}$ was taken into consideration. The mean discharge in the river (in the frame of this example the Elbe river, also a federal navigation waterway) was set to the mean discharge $\mathrm{MQ}=400$ $\mathrm{m}^{3} / \mathrm{s}$ whereas the peak flow was $\mathrm{Q}=4500 \mathrm{~m}^{3} / \mathrm{s}$. The time to peak was set to $48 \mathrm{~h}$. It was assumed that the river was $250 \mathrm{~m}$ wide and the longitudinal bottom slope was $\mathrm{I}=0.0003$. The elevation of the river bed was $102.0 \mathrm{~m}$ a.s.l. The Strickler coefficient of the river bed was $\mathrm{k}_{\mathrm{st}}=36 \mathrm{~m}^{1 / 3} / \mathrm{s}\left(\mathrm{n}=0.0277 \mathrm{~s} / \mathrm{m}^{1 / 3}\right)$. 


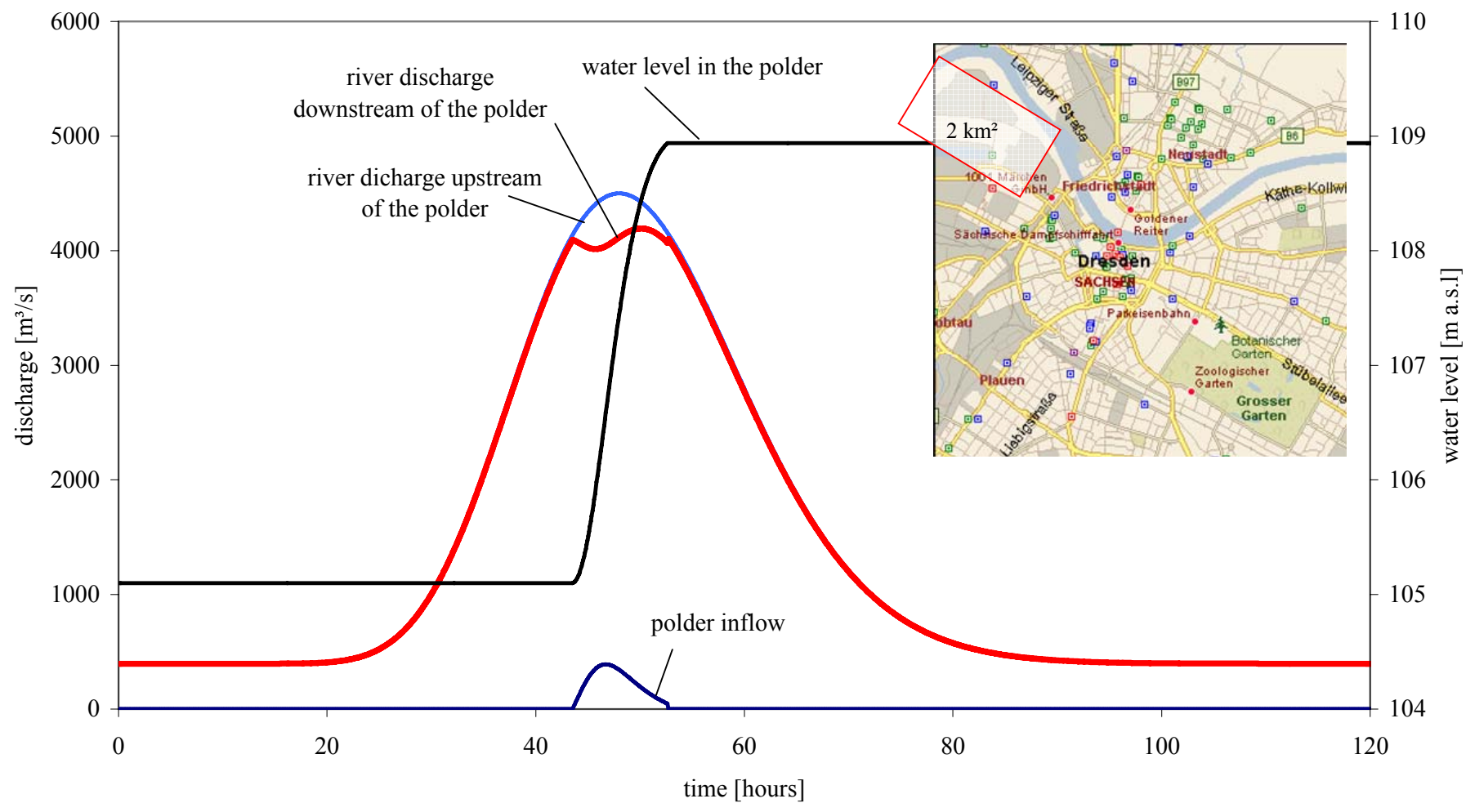

Figure 9. Example for controlled polder flooding with sufficient reduction of peak discharge.

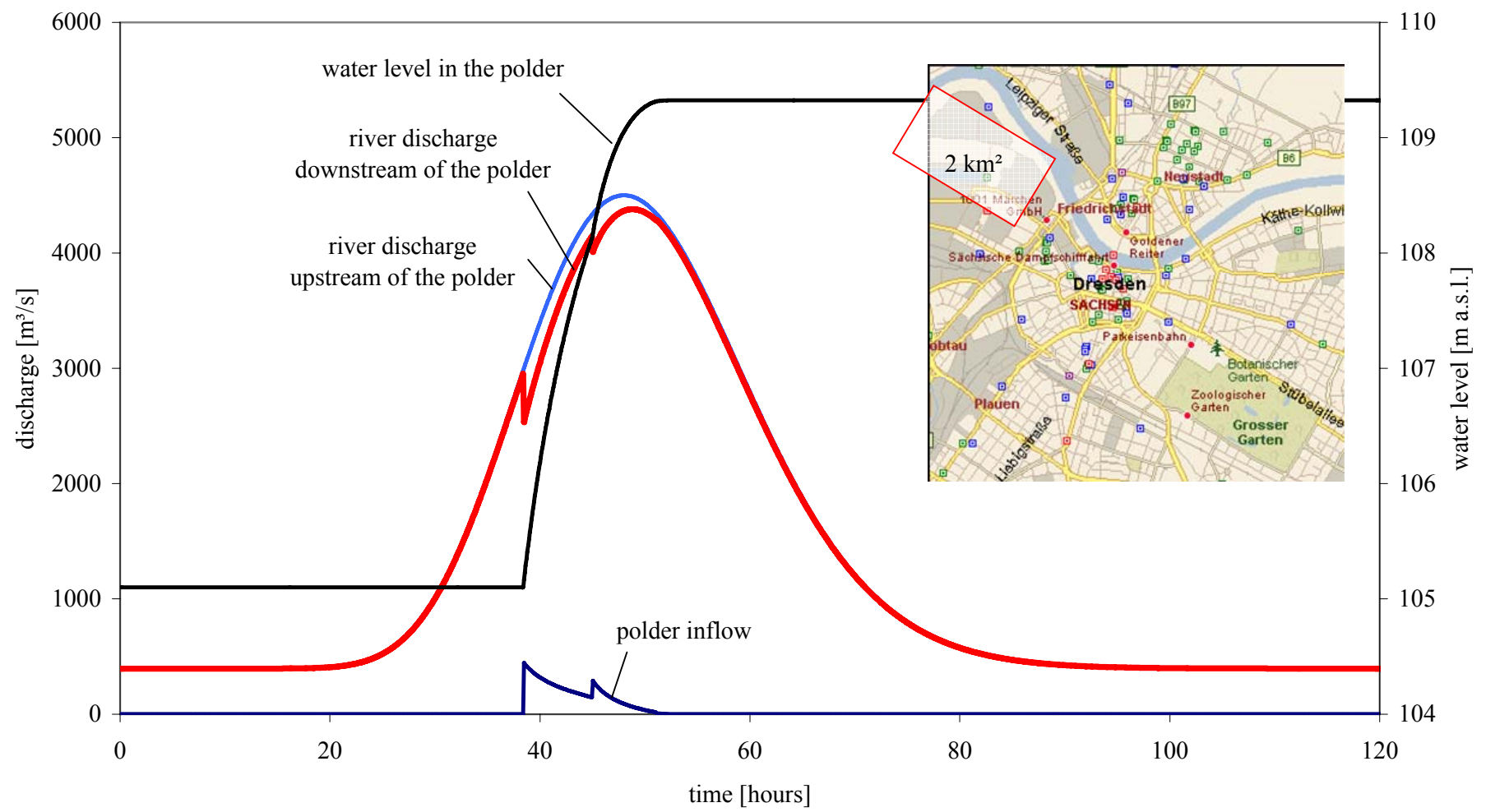

Figure 10. Insufficient peak discharge reduction due to inexact prediction of river flow discharge. 
The polder bottom was set to $105 \mathrm{~m}$ a.s.l. and the inflow of the polder had a fixed overflow crest at a level of $105.2 \mathrm{~m}$ a.s.1. There were two dike gates each $20 \mathrm{~m}$ wide. If the water level reached $108.0 \mathrm{~m}$ a.s.l. the $1^{\text {st }}$ of two dike gates was opened. When opening the $2^{\text {nd }}$ dike gate the water level had to be at $109.5 \mathrm{~m}$ a.s.1. The dike crest is set to $110.5 \mathrm{~m}$ a.s.1 and for the crest width $1414 \mathrm{~m}$ was chosen.

The calculation uses a time step of $\mathrm{dh}=0.08 \mathrm{~h}$. If the dike gates are opened in perfect matter just before the discharge reaches its maximum the peak reduction is more than $300 \mathrm{~m}^{3} / \mathrm{s}$, it is about $7 \%$ (figure 11).

Due to inexact forecast and an early opening of the inlets the retention effect could be completely lost. In figure 12 the discharge hydrograph is shown. The polder was flooded to early and the peak discharge reduction is less than $3 \%$.

It is obvious that the peak discharge reduction ability of a reservoir or a polder is very sensitive on opening time of the inflow gates and this decision needs a very good runoff forecast.

Flood damage reduction studies often recommended polders or the rebuilding of dikes more far away from the river to reduce the risk of inundation. But only controlled polders with controlled inflow gates have significant peak discharge reduction ability.

\section{CONCLUSIONS AND FURTHER INVESTIGATIONS}

A calculation procedure for the optimization of reservoir operation rules considering inundation damages as well as ecological impacts is presented.

The optimization of reservoir operation strategies needs a computation model and a multi criteria function.

A computation model can be established using available software and data describing the catchment areas and the reservoirs. The further issue is to connect these different models in an efficient way.

The description of optimization criteria is more complicated. It needs the combined consideration of monetary and non-monetary damages due to flood events. We have to remark a lack of data about the most of the non-monetary damages so that additional research has to be done.

\section{REFERENCES}

Aigner, D.; Bornschein, A. \& Pohl, R. 2002. Der Dammbruch von Glashütte. In Wasserwirtschaft, Wassertechnik; Heft 7: 6-10

Bornschein, A. \& Pohl, R. 2003. The Dam Break during the Flood in Saxon/Germany in August 2002. In Proc. $X X X$ IAHR-Congress, Thessalonica, Greece, August 2003
Bornschein, A. \& Pohl, R. 2005. Lessons learned from the 2002 flood in Saxony, Germany. In Proc. 40th Defra Flood and Coastal management Conference, York, England: 05B.3.1 - 05B.3.12

DVWK 1997. Maximierte Gebietsniederschlagshöhen für Deutschland. DVWK-Mitteilungen 29, Bonn, Germany

DWD 1997. Starkniederschlagshöhen für Deutschland. KOSTRA-DWD-2000, Deutscher Wetterdienst, Offenbach, Germany

LfUG 1993. Gewässerkundliche Hauptzahlen - Hydrologisches Handbuch Teil 1, Landesamt für Umwelt und Geologie des Freistaates Sachsen, Dresden, Germany

LfUG 2004. Ereignisanalyse - Hochwasser August 2002 in den Osterzgebirgsflüssen. Sächsisches Landesamt für Umwelt und Geologie, Dresden, Germany

LTV 2005. Daten zu den Einzugsgebieten der Weißeritz und der Müglitz sowie der Talsperren, Landestalsperrenverwaltung des Freistaates Sachsen, Pirna, Germany

Martin, H. \& Pohl, R. 2002. Hydraulic dam safety from the viewpoint of gate and valve operation. In Flood Defence 2002, Vol. 2, Science Press, Beijing, New York: 1438-1445

Pohl, R. 1988. Aspekte zur Freibordbemessung an Talspeichern. In Wasserwirtschaft-Wassertechnik 38(1): 15-17

Pohl, R. 1999. Estimation of the probability of hydraulichydrological failure of dams. In Proc. Int. Workshop on risk analysis in dam safety assessment Taipei, Taiwan, R.o.C.: $143-157$

Pohl, R. 2000. Failure frequency of gates and valves at dams and weirs. In Int. Journal on Hydropower \& Dams issue No. 6: 77 - 82

Pohl, R. \& Horlacher, H.-B. 1996. Safety aspects in reservoir operation: power utilization, water supply, freeboard allowance. In International conference on aspects of conflicts in reservoir development \& management London 3-5 Sept.: 443-451

US Army 1996. Risk-based analysis for flood damage reduction studies. Manual No. 1110-2-1619. Department of the Army, US Army Corps of Engineers, Washington, DC, USA 